\begin{tabular}{lll}
\hline institute & $\begin{array}{c}\text { CARADDE: Jurnal Pengabdian Kepada Masyarakat } \\
\text { https://journal.ilininstitute.com/index.php/caradde } \\
\text { Volume 1 | Nomor 2 | Februari | } 2019 \\
\text { e-ISSN: 2621-7910 dan p-ISSN: 2621-7961 }\end{array}$ & $\begin{array}{l}\text { Iin } \\
\text { DOI: https://doi.org/10.31960/caradde.v1i2.38 }\end{array}$ \\
\hline
\end{tabular}

\title{
Pelatihan Dan Pendampingan Kelompok Pemuda Dalam Peningkatan Pelayanan Dan Pengelolaan Kawasan Obyek Wisata Candi Cetho
}

\author{
Yustinus Windrawanto ${ }^{1}$, Sapto Irawan ${ }^{2}$, Setyorini ${ }^{3}$
}

\begin{tabular}{|c|c|}
\hline Key & bstrak. Sumber daya manusia merupakan salah satu faktor penting \\
\hline $\begin{array}{l}\text { Pelatihan; } \\
\text { pendampingan; } \\
\text { kelompok pemuda; } \\
\text { pengelolaan; } \\
\text { candi Cetho }\end{array}$ & $\begin{array}{l}\text { dalam berbagai bidang, termasuk dalam hal pengelolaan dan } \\
\text { pengembangan obyek wisata. Peningkatan sumber daya manusia } \\
\text { yang ada didaerah kawasan wisata dapat meningkatkan kemampuan } \\
\text { dalam pengelolaan dan pengembangan potensi yang ada didaerah } \\
\text { tersebut. Peningkatan sumber daya manusia dapat dilakukan melalui } \\
\text { berbagai kegiatan dan program. Oleh karena itu melalui program } \\
\text { pengabdian kepada masyarakat ini, melakukan pelatihan dan dan }\end{array}$ \\
\hline Core & pendampingan kepada dua kelompok pemuda PERADAH dan \\
\hline Pro & gelola bumi perkemahan dikawasan candi Cetho. Tujuan kegiatan \\
\hline U1 & yaitu untuk meningkatkan kemampuan dan keterampilan para \\
\hline W & semuda dalam pelayanan kepada para pengunjung kawasan candi \\
\hline Ema & Cetho dan meningkatan pengelolaan dan pengembangan bumi \\
\hline & $\begin{array}{l}\text { perkemahan. Hasil kegiatan peningkatan sumber daya manusia } \\
\text { dilakukan melalui pelatihan dan pendampingan kepada dua } \\
\text { kelompok pemuda PERADAH dan pengelola bumi perkemahan }\end{array}$ \\
\hline & fokus dan pokok materi tentang: Pelatihan komunikasi antar \\
\hline $\operatorname{Rec}$ & pribadi, Pelatihan manajemen kelompok, dan Pendampingan \\
\hline $\operatorname{Rev}$ & ERADAH. Sedangkan kepada kelompok \\
\hline Acce & dan pendampingan tentang: \\
\hline Published: $\mathrm{F}$ & $\begin{array}{l}\text { Pelatihan teknik memfasilitasi, Workshop pengembangan layanan } \\
\text { bumi perkemahan, Pelatihan manajemen kelompok, dan } \\
\text { Pendampingan kelompok. }\end{array}$ \\
\hline
\end{tabular}

his work is licensed under a Creative Commons Attribution

4.0 International License

\section{PENDAHULUAN}

Dusun Cetho merupakan salah satu daerah tujuan wisata yang berjenis wisata religi, budaya, alam, dan pendidikan, yang berada di Desa Gumeng, Kecamatan Jenawi, kabupaten Karanganyar, Jawa Tengah. Sebagai daerah tujuan wisata, saat ini Dusun Cetho memiliki suatu kawasan wisata meliputi : Candi Cetho, Candi Kethek, Puri Saraswati, jalur pendakian Gunung Lawu, Bumi Perkemahan, air terjun serendeng, dan berbagai tradisi masyarakat. Selain tujuan wisata, dusun Cetho juga merupakan salah satu jalur pendakian menuju ke gunung Lawu. Dusun Cetho merupakan desa terakhir sebelum memulai pendakian ke gunung Lawu. Sebagai dusun terakhir sebelum pendakian, maka secara otomatis menjadi tempat transit bagi para pendaki.

Sebagai salah satu daerah atau dusun tujuan wisata, tentu masyarakat sekitar juga terdampak baik secara langsung maupun tidak langsung. Dampak langsung yang dapat diamati yaitu, banyaknya warga sekitar yang menyediakan tempat-tempat penginapan, penyediaan lahan parkir bagi pengunjung, dan 
adanya warung-warung disepanjang jalan menuju lokasi dan disekitar lokasi wisata.

Dampak tidak langsung yaitu adanya peran serta masyarakat warga sekitar dalam berbagai kegiatan dan aktivitas yang ada di kawasan tersebut. Hal ini membawa pengaruh terbentuknya berbagai kelompok-kelompok masyarakat yang eksistensinya nampak dalam berbagai bentuk melalui keterlibatan dan kegiatan yang ada disekitar kawasan candi Cetho. Beberapa kelompok masyarakat yang terlibat antara lain PERADAH (kelompok pemuda Hindu), Relawan Cetho (Reco), Pengelola Bumi Perkemahan, kelompok pedagang, dan lainnya. Setiap kelompok memiliki kegiatan yang berbedabeda. Contohnya, kelompok PERADAH berfokus pada penyediaan kain kampuh bagi pengunjung Candi Cetho dan layanan tiket pengunjung puri Saraswati. Kain kampuh merupakan salah kain yang diikatkan kepada setiap pengunjung yang akan masuk kawasan wisata canti Cetho. Kelompok relawan Cetho berfokus pada layanan bagi para pendaki Gunung Lawu, dan kelompok pengelola Bumi Perkemahan yang berfokus pada layanan para penyewa bumi perkemahan.

Melalui hasil wawancara dengan para pemuda dan pengelola obyek wisata candi Cetho, bahwa mekanisme pelayanan kepada pengunjung belum ada standarisasinya, sehingga pelayanan antara petugas yang satu dengan yang lain akan berbeda-beda. Informasi senada juga didapatkan dari hasil wawancara dengan ketua kelompok pemuda, bahwa pelayanan kepada pengunjung yang datang dikawasan candi Cetho hanya berdasarkan kemampuan masing-masing orang yang bertugas. Selain itu, para petugas belum pernah mendapatkan pelatihan tentang standar pelayanan. Hal ini menimbulkan pelayanan yang berda-beda kepada para pengunjung, termasuk dalam hal pola komunikasi para petugas. Kondisi ini diperkuat pada saat pengamatan langsung terhadap para petugas baik di bagian ticketing, maupun pelayanan kain ketika melayani para pengunjung yang dilakukan oleh kelompok pemuda kain.

Kondisi serupa juga terjadi pada kelompok pengelola Bumi Perkemahan yang ada disekitar kawasan candi Cetho. Selain masalah pelayanan dan pola komunikasi,
Bumi Perkemahan ini mempunyai masalah pemasaran, sehingga Bumi Perkemahan kurang dikenal dikalangan masyarakat sekitar dan lingkungan luar. Hal ini berdampak pada minimnya pengguna atau penyewa bumi perkemahan di kawasan tersebut. Berdasarkan hasil observasi, masalah lain dibumi perkemahan yaitu letak geografis yang cukup terjal dan agak jauh dari perkampungan penduduk, serta masih minimnya fasilitas yang diperlukan.

Melihat fenomena tersebut, maka penulis menitikberatkan pada dua kelompok pemuda yaitu kelompok pemuda PERADAH yang melayani kain dibagian ticketing dan pengelola bumi perkemahan. Bentuk kegiatan yang ditawarkan yaitu berupa pendampingan masing-masing kepada kelompok pemuda. Program pendampingan akan dilakukan dalam kurun waktu sekitar 7 (tujuh) bulan dengan fokus kegiatan sesuai dengan karakteristik permasalahan dari masingmasing kelompok pemuda. Melalui program pendampingan ini diharapkan kelompok pemuda kain dapat meningkatkan pelayanan kepada para pengunjung, dan bagi pengelola bumi perkemahan dapat meningkatkan profesionalisme dalam pengelolaan bumi perkemahan.

\section{METODE}

Metode kegiatan pelatihan dan pendampingan dilaksanakan dalam bentuk pelatihan, workshop, dan pendampingan. Kegiatan pada masing-masing kelompok pemuda adalah sebagai berikut:

a. Kelompok Pemuda Kain (PERADAH)

Beberapa kegiatan yang dilakukan kepada kelompok ini yaitu:

1. Pelatihan komunikasi antar pribadi

Tujuan pelatihan ini adalah peningkatan kepercayaan diri para pemuda anggota kelompok yang bermuara pada kualitas dalam melayani para pengunjung candi. Pelatihan komunikasi perlu dilakukan (Rahmawati,2014) dan bermanfaat bagi pemandu wisata (Bahriyah, 2013).

2. Pelatihan manajemen kelompok

Tujuan pelatihan ini adalah peningkatan pengelolaan kelompok agar dapat berkembang dengan baik dan pelayanannya berkesinambungan. 
Pelatihan dengan metode PRA diyakini dapat membantu menyelesaikan masalah pengelolaan kelompok sebagaimana hasil pengabdian masyarakat yang dilakukan oleh Sonbait \& Widayati (2015) dan Wahab \& HIJRAH (tt).

3. Pendampingan kelompok

Melalui pendampingan ini, diharapkan hasil pelatihan dapat ditindaklanjuti dan dapat dilakukan pengembangan berdasarkan pengalaman yang muncul selama pendampingan.

b. Pengelola Bumi Perkemahan Beberapa kegiatan yang dilakukan kepada kelompok pengelola bumi perkemahan yaitu:

1. Pelatihan teknik memfasilitasi

Tujuan pelatihan ini adalah anggota kelompok mampu memfasilitasi kelompok-kelompok pengguna bumi perkemahan. Topik pelatihan antara lain ketrampilan dasar teknik memfasilitasi, teknik fasilitasi kegiatan dalam ruang dan luar ruang. Menurut beberapa penelitian (Hasdiansyah,2015; Baruwadi,2012), pelatihan dengan pendekatan yang tepat dapat meningkatkan sumber daya pemuda. Salah satu pelatihan yang penting bagi fasilitator adalah kemampuan komunikasi (Jumrana, 2015).

2. Workshop pengembangan bumi perkemahan

Melalui workshop ini, kelompok diharapkan mampu merancang layanan di bumi perkemahan dan merancang lokasi bumi perkemahan. Dengan demikian kelompok mampu melayani berbagai special interest pengguna bumi perkemahan. Penambahan wahana akan memberikan dampak ekonomis (Nurahmah, 2014). Namun tetap harus mempertimbangkan daya dukung ekosistem (Lucyanti dkk, 2013)

3. Pelatihan manajemen kelompok

Tujuan pelatihan ini adalah kelompok dapat meningkatkan pengelolaan dapat berkembang dengan baik dan pelayanannya berkesinambungan. Topik pelatihan yang akan disajikan antara lain konsep dasar manajemen kelompok dan pengembangan rencana strategis kelompok.

4. Pendampingan kelompok

Melalui pendampingan ini, diharapkan kelompok dapat menerapkan hasil pelatihan dan workshop. Selain itu, berdasarkan hasil pendampingan, dapat dilakukan pengembangan produk jasa hasil pelatihan.

\section{HASIL DAN PEMBAHASAN}

\section{Deskripsi Hasil Pelaksanaan Kegiatan}

Kegiatan pelatihan dan pendampingan kelompok pemuda di kawasan obyek wisata candi Cetho, merupakan kegiatan yang difokuskan kepada dua kelompok pemuda pelayanan kain (PERADAH) dipintu masuk candi dan kelompok pengelola bumi perkemahan. Dengan demikian, maka indikator keberhasilan kegiatan pada masingmasing kelompok pemuda sebagai berikut:

a. Kelompok pemuda kain (PERADAH)

1) Pelatihan komunikasi antar pribadi Luaran pelatihan ini adalah terlatihnya minimal 10 orang dalam pelatihan komunikasi antar pribadi. Pelatihan ini berlangsung 20 jam pertemuan yang terdiri dari 10 jam teori dan 10 jam praktek. Produk dari pelatihan ini adalah standar layanan verbal bagi pengunjung Candi Cetho.

2) Pelatihan manajemen kelompok Luaran pelatihan ini adalah terlatihnya minimal 10 orang dalam pelatihan menejemen kelompok. Pelatihan ini akan berlangsung dalam waktu 12 jam yang terdiri dari 5 jam teori dan 7 jam praktek. Produk dari pelatihan ini adalah rencana strategis kelompok.

3) Pendampingan kelompok

Luaran dari pendampingan ini adalah terdampinginya dan termonitornya minimal 30 orang dalam menerapkan hasil pelatihan. Pendampingan akan dilakukan sebanyak 3 kali.

b. Kelompok Pengelola Bumi Perkemahan

1) Pelatihan teknik memfasilitasi

Luaran dari pelatihan ini adalah terlatihnya minimal 10 orang dalam pelatihan teknik memfasilitasi. Pelatihan ini akan berlangsung dalam waktu 12 jam pertemuan yang terdiri dari 4 jam teori dan 8 jam praktek. Produk dari pelatihan ini adalah standar layanan fasilitasi pengguna bumi perkemahan. 


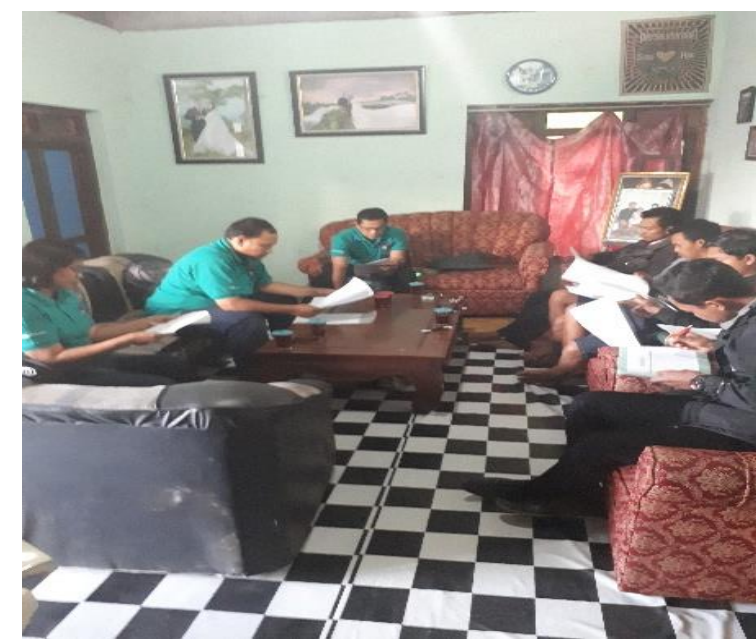

Gambar 1: Tim memberikan pelatihan

2) Workshop pengembangan layanan bumi perkemahan

Luaran dari pelatihan ini adalah terlatihnya minimal 10 orang dalam workshop pengembangan layanan bumi perkemahan. Workshop ini berlangsung dalam waktu 10 jam pertemuan yang terdiri dari 3 jam teori dan 7 jam praktek. Produk dari workshop ini adalah rencana pengembangan bumi perkemahan.

3) Pelatihan manajemen kelompok Luaran dari pelatihan ini adalah terlatihnya minimal 10 orang dalam pelatihan manajemen kelompok. Pelatihan ini akan berlangsung dalam waktu 10 jam pertemuan yang terdiri dari 5 jam teori dan 5 jam praktek. Produk dari pelatihan ini adalah rencana strategis kelompok.

4) Pendampingan kelompok

Luaran dari pendampingan ini adalah terdampinginya dan termonitornya minimal 10 orang dalam menerapkan hasil pelatihan. Pendampingan dilakukan sebanyak 3 kali.

\section{Keberhasilan Kegiatan}

Pelaksanaan kegiatan mengacu pada indikator ketercapaian program kegiatan pada masing-masing kelompok pemuda tersebut. Berdasarkan indikator ketercapaian program pada masing-masing kelompok pemuda, disajikan sebagai berikut:

a. Kelompok pemuda kain (PERADAH)

1) Pelatihan komunikasi antar pribadi

Kegiatan ini diikuti oleh 15 orang dalam pelatihan komunikasi antar pribadi. Topiktopik yang dilatihkan adalah lima aspek komunikasi antar pribadi berdasar teori Devito (2009). Kelima aspek tersebut adalah keterbukaan (openness), empati (empathy), sikap mendukung (supportiveness), sikap positif (positiveness), dan kesetaraan (equality). Pelatihan ini berlangsung 20 jam pertemuan yang terdiri dari 10 jam teori dan 10 jam praktek. Produk dari pelatihan ini adalah standar layanan verbal bagi pengunjung Candi Cetho.

2) Pelatihan manajemen kelompok

Kegiatan manajemen kelompok 16 orang dalam pelatihan menejemen kelompok. Topik-topik dalam pelatihan ini merupakan adaptasi dari konsep PRA. Pelatihan ini berlangsung dalam waktu 12 jam yang terdiri dari 5 jam teori dan 7 jam praktek. Produk dari pelatihan ini adalah rencana strategis kelompok.

3) Pendampingan kelompok

Kegiatan pendampingan kelompok ini diikuti oleh minimal 30 orang dalam menerapkan hasil pelatihan. Pendampingan akan dilakukan sebanyak 4 kali.

b. Kelompok Pengelola Bumi Perkemahan 1) Pelatihan teknik memfasilitasi

Kegiatan teknik memfasilitasi diikuti oleh 10 orang dalam pelatihan teknik memfasilitasi. Topik - topik dalam pelatihan ini diadaptasi dari Guide to being a Successful Facilitator (UNEVOC-UNESCO). Pelatihan ini berlangsung dalam waktu 12 jam pertemuan yang terdiri dari 4 jam teori dan 8 jam praktek. Produk dari pelatihan ini adalah standar layanan fasilitasi pengguna bumi perkemahan.

2) Workshop pengembangan layanan bumi perkemahan

Kegiatan workshop pengembangan layanan bumi perkemahan diikuti oleh 10 orang. Topik yang dibahas dalam workshop ini adalah bagian standar pelayanan menurut Permenpar no 24 tahun 2015 tentang Standar Usaha Bumi Perkemahan. Workshop ini berlangsung dalam waktu 10 jam pertemuan yang terdiri dari 3 jam teori dan 7 jam praktek. Produk dari workshop ini adalah rencana pengembangan bumi perkemahan.

3) Pelatihan manajemen kelompok

Kegiatan pelatihan manajemen kelompok telah diikuti oleh 10 orang. Dalam pelatihan manajemen kelompok, Topik yang dibahas adalah bagian standar pengelolaan menurut Permenpar no 24 tahun 2015 tentang Standar Usaha Bumi Perkemahan Pelatihan ini telah berlangsung dalam waktu 10 jam 
pertemuan yang terdiri dari 5 jam teori dan 5 jam praktek. Produk dari pelatihan ini adalah rencana strategis kelompok.

4. Pendampingan kelompok

Kegiatan pendampingan kelompok ini telah diikuti oleh 12 orang. Pendampingan telah dilakukan sebanyak 3 kali.

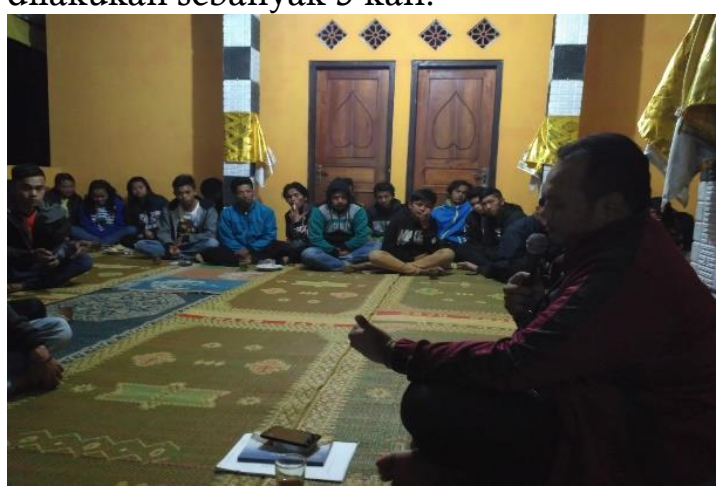

Gambar 2: Kegiatan dalam Pelatihan

Selain kegiatan tersebut, para pemuda juga diberi pengalaman dalam pengelolaan obyek wisata dan bumi perkemahan melalui kegiatan kunjungan belajar di Yogyakarta dan sekitarnya. Kunjungan belajar dilaksanakan pada hari Sabtu, 28 Juli 2018 dan diikuti oleh 40 pemuda, baik perwakilan pemuda kelompok kain dan pengelola bumi perkemahan obyek wisata candi Cetho. Kegiatan kunjungan belajar dilaksanakan pada dua tempat tujuan yaitu Kemah Budaya yang ada dibumi perkemahan dikomplek Candi Prambangan Yogyakarta dan Pengelolaan obyek wisata Tebing Breksi yang berada di Yogyakarta. Pada kegiatan Kemah Budaya, para pemuda diajak untuk melihat langsung aktivitas di kegiatan Kemah Budaya. Selain itu juga dilakukan paparan oleh para panitia pelaksana dan dilanjutkan dengan diskusi, serta tanya jawab. Melalui kegiatan ini para pemuda mempunyai pengalaman langsung tentang penyelenggaraan kemah budaya, mengetahui bentuk kegiatan yang dilakukan, pengelolaan kegiatan, serta pengelolaan bumi perkemahaan.

Kegiatan kedua yaitu dilaksanakan diobyek wisata tebing Breksi di Yogyakarta. Dilokasi ini, para pemuda diberi pengalaman nyata melalui pengamatan langsung dari pelayanan tiket masuk, pengelolaan perparkiran, dan pengelolaan didalam lokasi wisata. Melalui kegiatan ini para pemuda mendapat pengarahan langsung dari narasumber pengelola utama tebing Breksi.
Para pemuda/peserta mendapat wawasan pengetahuan meliputi sejarah singkat dan latar belakang munculnya obyek wisata Tebing Breksi, mekanisme pengelolaan, dan rencana pengembangan kedepan. Kegiatan dilanjutkan dengan diskusi dan tanya jawab dengan narasumber.
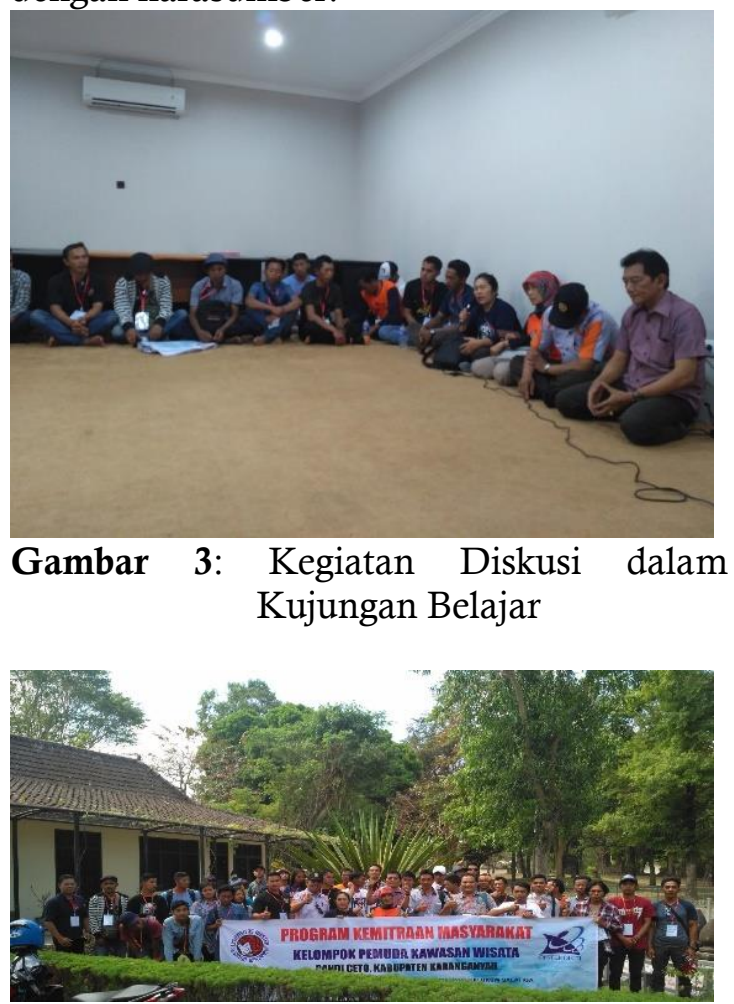

Gambar 4: Kunjungan Belajar ke Yogyakarta

Kegiatan pelatihan dan pendampingan ini secara tidak langsung membawa dampak meningkatkan kecakapan hidup (life skill) para pemuda. Seperti halnya bahwa ciri pembelajaran life skill yaitu: (1) terjadi proses identifikasi kebutuhan belajar; (2) terjadi proses penyadaran untuk belajar bersama; (3) terjadi keselarasan kegiatan belajar untuk mengembangkan diri, belajar, mandiri, usaha mandiri, dan usaha bersama; (4) terjadi proses penguasaan kecakapan personal, sosial, vokasional, akademik, manajerial, dan kewirausahaan; (5) terjadi proses pemberian pengalaman dalam melakukan pekerjaan dengan benar, menghasilkan produk bermutu; (6) terjadi proses interaksi saling belajar dari ahli; (7) terjadi proses penilaian kompetensi, dan (8) terjadi proses pendampingan teknis untuk bekerja atau membentuk usaha bersama (Depdiknas, 2003).

Melalui berbagai kegiatan tersebut, para pemuda baik kelompok kain maupun 
pengelola bumi perkemahan mendapatkan tambahan wawasan, pengetahuan dan keterampilan terkait dengan pengelolaan dan pengembangan obyek wisata. Berdasarkan pengamatan dan observasi lingkungan yang ada di kawasan Candi Cetho, banyak potensi yang bisa digali, dikembangkan, serta ditingkatkan untuk menjadi destinasi wisata.

Oleh karena itu peran serta dan pengembangan sumber daya manusia, khususnya pemuda merupakan salah satu factor penting untuk mengembangkan dan meningkatkan potensi wisata didaerahnya. Berbekal pengetahuan dan keterampilan yang dimiliki, para pemuda diharapkan dapat meningkatkan pelayanan, pengelolaan obyek wisata yang ada di sekitar candi Cetho. Selain itu dapat merencanakan pengembangan oybek wisata candi Cetho dan bumi perkemahan yang ada dikawasan tersebut.

\section{SIMPULAN DAN SARAN}

Kawasan obyek wisata candi Cetho, merupakan salah satu destinasi wisata yang cukup menjanjikan. Selain tujuan utama wisata candi Cetho, dikawasan tersebut mempunyai potensi dan peluang untuk pengembangan destinasi wisata dan bumi perkemahan. Peluang tersebut belum didukung dengan sumber daya manusia, khususnya pemuda didaerah sekitar. Oleh karena itu perlu ada upaya untuk meningkatkan sumber daya manusia supaya dapat menjadi tuan rumah yang ramah bagi para wisatawan, mampu melayani dengan baik, dan dapat meningkatkan pengelolaan, serta pengembangan destinasi wisata yang ada didaerahnya. Peningkatan sumber daya manusia dilakukan melalui pelatihan dan pendampingan kepada dua kelompok pemuda PERADAH dan pengelola bumi perkemahan dengan fokus dan pokok materi tentang: Pelatihan komunikasi antar pribadi, Pelatihan manajemen kelompok, dan Pendampingan kelompok, bagi kelompok PERADAH. Sedangkan kepada kelompok pengelola bumi perkemahan pelatihan dan pendampingan tentang: Pelatihan teknik memfasilitasi, Workshop pengembangan layanan bumi perkemahan, Pelatihan manajemen kelompok, dan Pendampingan kelompok.

Berdasarkan hasil kegiatan yang telah dilakukan, menyarankan agar para pemangku kepentingan dikawasan obyek wisata candi Cetho untuk mengembangkan sumber daya manusia untuk dapat meningkatkan pelayanan dan pengelolaan obyek wisata tersebut. Selain itu perlu meningkatkan kerjasama dan memperluas jejaring dengan pihak-pihak terkait untuk dapat mengembangkan potensi wisata yang ada, baik wisata budaya, wisata religi, wisata alam, wisata kuliner, dan pengembangan serta inovasi lainnya.

\section{DAFTAR PUSTAKA}

Bahriyah, Euis Nurul. 2013. Komunikasi Interpersonal Pemandu Wisata dalam Mengenalkan Indonesia pada Wisatawan Mancanegara. Tersedia dalam http://euisnurulb.weblog.esaunggul.ac .id/wpcontent/uploads/sites/2284/20 14/06/Penelitian-Internal-2013-EuisNurul-B.pdf

Baruwadi, Romy. 2012. Pengembangan Model Pembelajaran Andragogi Untuk Meningkatkan Kecakapan Hidup Bagi Pemuda Putus Sekolah Di Kota Gorontalo. S3 thesis. Universitas Pendidikan Indonesia.http:// repository.upi.edu/8473/6/d_pls_0809 587_chapter5.pdf

Devito, Joseph A. 2009.Human Communication. The Basic Course.Boston:Pearson Education

Hasdiansyah, Andi. 2015. Evaluasi Keberhasilan Program Pelatihan Pemuda dalam Meningkatkan Sumber Daya Manusia (Studi pada Basic Training HMI Korkom UNM). S2 thesis. UNY. Tersedia dalam http:// eprints.uny.ac.id/25886/

Jumrana.2015.Fasilitator Dalam Komunikasi Pemberdayaan Masyarakat. Profetik: Jurnal Komunikasi 8.1 Tersedia dalam http://ejournal .uinsuka.ac.id/isoshum/profetik/article/vi ewFile/1098/1011 
Windrawanto, Irawan, Setyorini. Pelatihan dan Pendampingan Kelompok

Lucyanti, Sylvia, Boedi Hendrarto, dan Munifatul Izzati. 2013. Penilaian Daya Dukung Wisata di Obyek Wisata Bumi Perkemahan Palutungan Taman Nasional Gunung Ciremai Propinsi Jawa Barat. Prosiding Seminar Nasional Pengelolaan Sumberdaya Alam dan Lingkungan. Tersedia dalam http://eprints.undip.ac.id/40669/1/03 5-Silvia_Lucyanti.pdf

Nurahmah, Anindyah. 2014. Dampak Ekonomi Dan Strategi Pengelolaan Ekowisata Di Wana Wisata Cikole Kabupaten Bandung Barat. Skripsi FEM IPB. Tersedia dalam http://repository.ipb.ac.id/jspui/bitstr eam/123456789 /69450/1/H14anu.pdf

Rahmawati, Amrina Fitri. 2014. Pola Komunikasi Pemandu Wisata (Guide) Kampung Wisata Batik Kauman
Surakarta . Journal of Rural and Development. Volume V No. 2 Agustus 2014. Tersedia dalam https://jurnal.uns.ac.id/rural-anddevelopment/article /download/ $848 / 830$.

Sonbait, Lukas Yowel dan Trisiwi Wahyu Widayati. 2015. Pembenahan Manajemen UKM Kelompok Peternak Agri Makmur Dan Kelompok Peternak Acap Di Distrik Prafi Kabupaten Manokwari. Udayana Mengabdi. Volume15 No 1. Tersedia dalam http://ojs.unud.ac.id/index.php/jum/ article/ download/13208/8887.

Wahab, A., \& HIJRAH, Y. Pemberdayaan Petani Perempuan Korban Konflik Melalui Pengembangan Teknologi dan Akses Pasar. Yayasan HIJRA 